\title{
Reasons of the gap between Outcome Characteristics of Private Higher Education, and Job Requirements in the Private Sector in Egypt (Reasons related to the community and the graduates)
}

\author{
Hosam M. Ramy ${ }^{1^{*}}$ Osama A. Abdella ${ }^{2}$ \\ 1. College of Business Administration, Majmaah University, P.O Box 66, Majmaah 11952 - Kingdom \\ Saudi Arabia \\ 2. College of Management and Technology, Arab Academy for Science and Technology (AAST), P.O. Box \\ 1029, Miami, Alexandria, Egypt \\ * E-mail of the corresponding author: h.ramy@mu.edu.sa
}

\begin{abstract}
This research is designed to measure the reasons of the gap (miss-fit) between the outcome characteristics of the private higher education and the job requirements in the private sector in Egypt. Specifically, the reasons related to the community and the graduates themselves are analysed, investigated and discussed. The exploratory research has shown that the reasons related to the Egyptian community are summarized in the Egyptian society's perspective towards private higher education. Where the reasons related to the graduates are summarized in the benefits of the private higher education to its graduates.

For the reasons related to the community, the researchers found that the preference of some majors, the vision of the community as regards universities, and the vision of the community concerning scientific research are confirmed to be causes of the gap from the academic staff members' and businessmen's points of view. For the reasons related to the graduates, we found that the qualifications of the graduates for the practical life and the benefits from their study are confirmed to be causes of the gap.

Consequently, the researchers can conclude that the society's perspective of the private higher education and the benefits of the private higher education to its graduates affect the gap between the outcome characteristics of the private higher education and job requirements in the private sector in Egypt.
\end{abstract}

Keywords: private higher education, education outcome, private sector in Egypt

DOI: $10.7176 / \mathrm{JAAS} / 62-06$

Publication date:March $31^{\text {st }} 2020$

\section{Introduction}

From earliest times, education and religion were inseparable in Egypt. Modern secular education was introduced by Mohammed Ali, who was appointed governor of Egypt in 1805. From the very beginning, science education was highly valued and encouraged in the Egyptian educational system. Since then, the system has undergone some phases in which the wielders of power pursued different interest (Emira, 2014).

In 1976, President Sadat said that the Egyptian educational system should be freed from traditional thoughts, types, structures, trends, and methodologies. He emphasized the need for a well-integrated educational program that would accent the development of mind, body, and spirit in a balanced way (El-Awady, 2013; Maher, 2018)

The basic goals of the Egyptian society are, firstly, to advance scientifically and technologically to provide for the needs of all Egyptians and, secondly, to assure the self-fulfilment of each individual through processes that foster and preserve the dignity and worth of all human beings in Egypt and the world. Egyptian leaders, since the 1952 Revolution, have been committed to quality education with equality in educational opportunity for everyone deemed essential to the attainment of these goals (EACEA, 2017).

Therefore, education is seen as playing an important role in the future development of society and as a basic human right. This includes both the training of human resources and the fostering of national integration (Tan et al., 2017).

The Egyptian educational system consists of general education, technical education, vocational education, and vocational training. General education starts in primary schools and leads, via general preparatory schools and general secondary schools, to higher education (represented in the higher institutes and universities) (EACEA, 2017). Higher education is one of the most important activities organized in modern societies. It creates a demanding but rewarding environment in which individuals may realize their creative and intellectual potential (El-Awady, 2013). 
Higher education institutions (HEIs) should work for the welfare of the society by creating new knowledge, providing skills and human social development. Private Higher education institutes should be closely monitored by the Ministry of higher education, regarding their high tuition fee, degree programs and enrolment into various programs without the ministry's approval (Ali et al., 2018).

The teaching methodology employed in higher education institutions should, firstly, foster and build the personality of each individual to become independent, self-directed, and self-controlled in ways that would help him understand and assume his role in the Egyptian society and in the whole world and, secondly, combine the formal learning of school with social and economic activities and real-life needs (Aring, 2012).

\section{Research Problem}

In order to define the research problem, focus groups were conducted with the following groups:

1) A number of top managers, mostly human resources managers who are responsible for training in private sector companies in Egypt.

2) A number of AAST academic staff members.

3) A number of AAST graduates who are currently working in the private sector in Egypt.

The researchers concluded that all the participants agreed that there is a gap between the outcome characteristics of the private higher education and the private labour market requirements in Egypt. The participants cited some phenomena which illustrate this gap. These phenomena included the following:

1) The preparation skills level of the graduates of the private educational sector is relatively low. Respectively, this leads to a need for training the graduates before recruitment.

2) The number of graduates in some certain fields is high in comparison to other specialized fields. This leads to widening the employment-outcomes gap, especially in some specific fields such as Business and Tourism.

3) The unemployment job fit, which leads to weakening their skills and knowledge about the job. This can be considered due to the culture of the community, as the unemployment rate is high.

Based on the previous discussion, the importance of this study becomes highly apparent, which led the researchers to investigate this gap in order to identify its notion and roots. Thus, the research problem is formulated in the following main question:

"What are the reasons that lead to the existence of the gap (miss-fit) between outcome characteristics of the private higher education and job requirements in the private sector in Egypt?"

In this research, the researchers focus on the reasons related to the Egyptian community and those related to the graduates. These reasons are:

1) Reasons related to the Egyptian community, which are represented in the Egyptian society's perspective towards private higher education.

2) Reasons related to the graduates, which are represented in the benefits of the private higher education to its graduates.

\section{Research Objectives}

The study aims to achieve the following objectives:

1) Identifying the reasons related to the Egyptian community and those related to the graduates behind the gap (miss-fit) between outcome characteristics of the private higher education and job requirements in the private sector in Egypt.

2) Testing the research hypotheses.

\section{Importance of Research}

The importance of the study stems from two basic dimensions: 


\subsection{Theoretical Importance}

1) This study is considered to be one of the first studies in Egypt that investigated the reasons of the gap between outcome characteristics of the private higher education and job requirements in the private sector in Egypt. All the previous studies that dealt with higher education in Egypt focused on studying how to improve the higher education sector using certain tools and techniques.

2) This study is considered a theoretical guide for many researchers in the future to explore the real reasons behind the existence of the gap, and a tool for suggesting solutions to minimize this gap.

3) The study deals with the labour market from all different perspectives, including the community, the graduates and the labour market. Therefore, we can generalize the results of the study over the whole higher education sector whether private or public and to make a comparison between them in order to know which is better and focus on it to accelerate the higher education improvement cycle in Egypt.

\subsection{Practical Importance}

This study has practical importance on the private higher education level, the overall higher education level, the Egyptian community level, and the Egyptian private labour market level. On the Egyptian society and community level the study can:

1) Improve the role of Egyptian universities in effectively preparing human resources, which are be the most valuable investment assets in any community.

2) Help to change the Egyptian community's vision of higher education and realize the importance of a lot of majors, and trying to promote the balance between the number of graduates of each major and the requirements of the labour market.

3) Help to change the Egyptian community's vision of the universities' role, and to get the universities responsible for cooperating in solving the different problems of the higher education in the community.

\section{Literature Review}

The last decade has witnessed a significant growth of private higher education around the world. The growth included the number of private education providers, and also the growing number of students. While some countries are experiencing trend growth, others are witnessing decline. Some of the reasons for the decline include increased regulation and stringent accreditation and reaccreditation of higher education institutions and courses, government policies to encourage the growth of public universities (Shah et al., 2019).

The introduction of private HEIs to the landscape of higher education in Egypt reflects a direction for change in the system that is congruent with the global experience. The presence of these new players has been mandated by higher education massification, pressure on state budget, and the global tide of neoliberalism in higher education. These new players replicate the teaching approaches of public HEIs and pay little attention to quality assessment and education outcomes, similar to their public counterparts (Barsoum, 2017).

\subsection{The Private Higher Education Perspective in Egypt}

Azam (2018) studied the fit between the efficiency of the private higher education and the labour market requirements in Saudi Arabia. From this study, she concluded that the perspective of the community to higher education affects the fit. Where, the discrimination between majors, the vision of the community to the role of universities, and the vision of the community to the scientific research are the most important factors that affect the perspective of the community concerning higher education.

The Egyptian community still looks to the university and the academic staff members as a separate entity of high social position in the community and its role is not to solve the problems of the society (Assaad et al., 2018). Where, universities contribute to the cultural and political life of modern societies. They are not only the source of expertise on everything, but are also the place where controversial issues are debated in an atmosphere of inquiry. Universities are among the few places in modern society where objective analysis takes place. It is not surprising that so many respected experts hold appointments in universities. Academic institutions are central to a civil society and have, under sometimes difficult circumstances, been able to maintain their independence (Hadidi and Kirby, 
2016).

The Egyptian community's look towards the scientific research is quite similar. The Egyptian community sees the scientific research useless and a secret of the universities and cannot be applied to serve the society (Assaad et al., 2018). Where, universities are the key research institutions in most countries. They are the central source for basic research, and as such have provided the underpinning of many of the innovations of modern society. Universities are the initial sources of new knowledge in almost all fields. They combine research with teaching in an atmosphere of free inquiry that provide the necessary conditions for productive research (Hyde, 2013)

The discrimination between majors led to the increasing number of students in some majors instead of others. This in turn led to the mismatch between the education outcomes and the labour market requirements. Therefore, it is important to balance the number of students in each major with the major requirements in the labour market and the society, and encourage the technical and professional education (Krafft, 2018).

\subsection{The Benefits of the Private Higher Education to the Graduates}

Knowing what you know and don't know sharpens learning. Students need appropriate feedback on performance to benefit from courses. In getting started, students need help in assessing existing knowledge and competence. In classes, students need frequent opportunities to perform and receive suggestions for improvement. At various points during college and at the end students need chances to reflect on what they have learned, what they still need to know, and how to assess themselves (Tolliver et al., 2018).

One of the studies saw that: Students need to be able to enjoy learning, for the sake of conceptual understanding, not for the singular purpose of writing an exam. The educators and teachers do need to ensure that their students are able to learn efficiently in the classroom and utilize their skills to their maximum potential. Also, students should receive active learning in their classes because this prepares them for the workplace by developing the required skills, enhancing them to learn better and creating a more engaging and enjoying learning environment (Beyleveld et al., 2019).

Education is the basic building block of human capital. It is through education that knowledge and skills are developed, enhancing more than simply the ability of labour to perform. Weiss (2018) states that "students are not taught civics, art, or music solely in order to improve their labour productivity, but their lives and make them better citizens", suggesting that education people provide additional value to a nation (Kottelenberg and Lehrer, 2019)

Knowledge can lead to competitive advantage in HEIs. Managing and sharing knowledge, as a strategic resource, is one of the foundational weapons that enable universities to increase their competitive advantage in the current competitive market towards making structural changes that make product and process innovation part of daily task for all staff in HEIs (AL Husseini \& Elbeltagi, 2019).

How students perform academically is a key to their education success. The government and other national and international organizations sponsor assessments to measure learning outcomes. The results of these assessments sometimes show mixed results and can be interpreted differently, depending on the definition of academic success used. For example, some international assessments measure performance by examining student achievement relative to that of their peers in other countries. National assessments, in contrast, often evaluate performance relative to predefined standards. Assessments that measure academic performance over several years can judge academic success by examining how much students average scores improve over time (Hicks et al., 2017).

Private HEIs have diversified their teaching methodologies to cater to the needs of regulatory bodies, such as the Bankseta. The business-like nature of private HEIs provides a platform from which they are client-oriented, focusing on delivering over and beyond the needs of the client. This atmosphere encourages innovation, diversification and attention to detail (Nukunah et al., 2019).

Another aspect of learning outcomes is how much students learn about their country and what it means to be a good citizen. Recent research has shown that college students and adults demonstrate little interest in politics or activism and a limited knowledge of basic civic related subjects (Zlatkin-Troitschanskaia et al., 2016).

Business and marketing managers who have a deeper understanding of the mediating effect of student satisfaction are better equipped to devise a marketing strategy that influences students' choice in an education institution, which in turn generates more profits by enhancing student loyalty (Tan et al., 2017) 


\section{Data Analysis and Results}

\subsection{First Hypothesis}

H1: There is a relationship between Reasons related to the Egyptian society, and the gap between the outcome characteristics of the private higher education and the job requirements in the private sector in Egypt.

To test this hypothesis, the researchers must test one sub-hypothesis which represents the reasons related to the Egyptian society. This sub-hypothesis is:

H1.1: There is a relationship between the society's perspective to private higher education in Egypt, and the gap between the outcome characteristics of the private higher education and the job requirements in the private sector in Egypt.

To test this sub-hypothesis, the researchers collected the opinions of the academic staff members, and businessmen of the private sector in Egypt, about the society's perspective toward private higher education in Egypt. This will be measured through three variables: the preference of some majors, the vision of the community toward the universities, and the vision of the community to the scientific research.

The t-test is performed to test this opinion. Table (1) and Table (2) show the results of this test for the academics and businessmen opinions respectively. From the tables, it is clear that the significance values of the test for the three variables are less than 0.05 . Therefore, there is a significant difference from the test value. The $95 \%$ confidence interval of the difference shows that the lower and upper bounds are both positive. Therefore, the preference of some majors, the vision of the community toward the universities, and the vision of the community toward the scientific research do affect the gap from the academics and businessmen point of views.

Table (1): T-test outputs for the academics' opinions about the variables that affect the society's perspective towards Egyptian private higher education

\begin{tabular}{|c|c|c|c|c|c|c|}
\hline & \multicolumn{6}{|c|}{ Test value $=\mathbf{3}$} \\
\hline & \multirow[b]{2}{*}{$\mathbf{t}$} & \multirow[b]{2}{*}{ df } & \multirow{2}{*}{$\begin{array}{c}\text { Sig. } \\
\text { (2-tailed) }\end{array}$} & \multirow{2}{*}{$\begin{array}{c}\text { Mean } \\
\text { Difference }\end{array}$} & \multicolumn{2}{|c|}{$\begin{array}{c}95 \% \\
\text { Confidence } \\
\text { Interval of the } \\
\text { Difference }\end{array}$} \\
\hline & & & & & Lower & Upper \\
\hline Preference of some majors & 7.504 & 59 & .000 & 1.01667 & .7456 & 1.2878 \\
\hline $\begin{array}{l}\text { The vision of the community } \\
\text { towards the universities }\end{array}$ & 2.445 & 59 & .017 & .46667 & .0848 & .8485 \\
\hline $\begin{array}{l}\text { The vision of the community } \\
\text { towards the scientific research }\end{array}$ & 4.722 & 59 & .000 & .80000 & .4610 & 1.1390 \\
\hline
\end{tabular}


Table (2): T-test outputs for the businessmen's opinions about the variables that represent the society's perspective towards Egyptian private higher education

\begin{tabular}{|c|c|c|c|c|c|c|}
\hline & \multicolumn{6}{|c|}{ Test value $=3$} \\
\hline & \multirow[b]{2}{*}{$\mathbf{t}$} & \multirow[b]{2}{*}{ df } & \multirow{2}{*}{$\begin{array}{c}\text { Sig. } \\
\text { (2-tailed) }\end{array}$} & \multirow{2}{*}{$\begin{array}{c}\text { Mean } \\
\text { Difference }\end{array}$} & \multicolumn{2}{|c|}{$\begin{array}{c}95 \% \\
\text { Confidence } \\
\text { Interval of the } \\
\text { Difference }\end{array}$} \\
\hline & & & & & Lower & Upper \\
\hline Preference of some majors & 7.610 & 149 & .000 & .76667 & .5676 & .9657 \\
\hline $\begin{array}{l}\text { The vision of the community } \\
\text { towards the universities }\end{array}$ & 8.890 & 149 & .000 & .82000 & .6377 & 1.0023 \\
\hline $\begin{array}{l}\text { The vision of the community } \\
\text { towards the scientific research }\end{array}$ & 10.6 & 149 & .000 & .99333 & .8078 & 1.1788 \\
\hline
\end{tabular}

Also the Kolmogorov-Smirnov (KS) and Mann-Whitney (MW) tests are conducted to test if there is a significant difference between the opinions of the academics and businessmen for the three variables. All the significance values are greater than 0.05 . Therefore the null hypothesis is not rejected. Consequently, there is no significant difference between the opinions of the academics and businessmen.

From the previous analysis, the researchers can conclude that the preference of some majors, the vision of the community towards the universities, and the vision of the community towards the scientific research, are confirmed to be causes of the gap from the academic staff members' and the businessmen's points of views. Consequently, the researchers can conclude that the society's perspective of the private higher education in Egypt affects the gap between the outcome characteristics of the private higher education and the job requirements in the private sector in Egypt.

Therefore, there is a relationship between the reasons related to the Egyptian society, and the gap between outcome characteristics of the private higher education and job requirements in the private sector in Egypt.

It is worth noting that the academic staff members added other causes of the gap, such as:

- $\quad$ There are no clear criteria for accepting students in universities.

- There is no good system for student evaluation.

- There is no suitable system for examination.

- The scientific research is not related to the real problems of the society.

- There is no suitable system for the evaluation of the academic staff members.

- Most of the graduates have jobs not related to their majors.

- The universities cannot develop the skills of the students to match the labor market.

- Drawbacks of the university system itself.

Also, the businessmen added the other following causes of the gap:

- The current educational system cannot give the student the opportunity to invent and innovate.

- $\quad$ Scarcity of modern educational media.

- Deficiency of training programs.

- Remoteness of academic courses form discussing the community's real problems.

- Remoteness of the graduation projects and scientific researchers from the community's real problems.

- Inability of the university to build the personality and the skills of the students. 


\subsection{Second Hypothesis}

H2: There is a relationship between Reasons related to the graduates themselves, and the gap between the outcome characteristics of the private higher education and the job requirements in the private sector in Egypt.

To test this hypothesis, the researchers must test one sub-hypothesis which represents the reasons related to the graduates themselves. This sub-hypothesis is:

H2.1: There is a relationship between the benefits of the higher education to the graduates, and the gap between the outcome characteristics of the private higher education and the job requirements in the private sector in Egypt.

To test this sub-hypothesis, the researchers collected the opinions of the academic staff members and AAST graduates, about the benefits of the higher education to the graduates. This will be measured through two variables: the qualifications of the AAST graduates for the practical life from the academic staff members' point of view, and the benefits of the graduates from higher education in the practical life from the AAST graduates' point of view. In the following section, the researchers will discuss each variable separately:

\subsubsection{The Qualification of the AAST Graduates for the Practical life}

Table (3) shows the results of the t-test for this sub-hypothesis according to the academics' opinions. It is clear from the table that the significance is less than 0.05; therefore, there is a significant difference from the test value (neutral opinion). The $95 \%$ confidence interval of the difference shows that the lower and upper bounds are both positive. Consequently, the graduates are qualified for the practical life.

Table (3): T-test outputs for the academics' opinions about the level of qualification of graduates

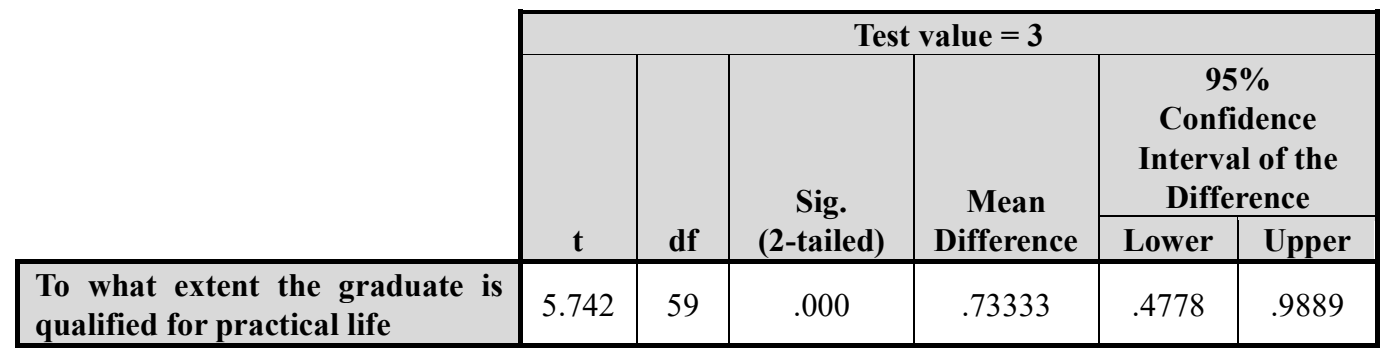

\subsubsection{The Benefits of the AAST Graduates from their Study}

Table (4) shows the t-test results of the opinion of the AAST graduates about their benefit from the study. From the table, it is clear that the significance is less than 0.05; therefore, the researchers rejects the null hypothesis that the AAST graduates have no benefit from their university study in practical life. This means that the graduates of the AAST benefit from their study.

Table (4): T-test outputs for the AAST graduates' opinions about the benefits from study

\begin{tabular}{|c|c|c|c|c|c|c|}
\hline & \multicolumn{6}{|c|}{ Test value $=\mathbf{3}$} \\
\hline & \multirow[b]{2}{*}{$t$} & \multirow[b]{2}{*}{ df } & \multirow{2}{*}{$\begin{array}{c}\text { Sig. } \\
\text { (2-tailed) }\end{array}$} & \multirow{2}{*}{$\begin{array}{c}\text { Mean } \\
\text { Difference }\end{array}$} & \multicolumn{2}{|c|}{$\begin{array}{c}95 \% \\
\text { Confidence } \\
\text { Interval of the } \\
\text { Difference } \\
\end{array}$} \\
\hline & & & & & Lower & Upper \\
\hline $\begin{array}{l}\text { To what extent the graduate is } \\
\text { qualified for practical life }\end{array}$ & 10.157 & 199 & .000 & .78500 & .6326 & .9374 \\
\hline
\end{tabular}

The KS and the MW tests are used to test if there is a significant difference between the opinions of the academic staff members and the AAST graduates. These tests support that there is no significant difference between the two opinions, where the significance of the KS test is 0.972 (greater than 0.05) and the MW test significance is 0.480 (greater than 0.05). 
To check the effect of these two variables (the benefits of the graduates from higher education in the practical life, and the qualifications of the AAST graduates for the practical life) on the gap, the researchers calculated the correlation coefficient between these variables and the fit between the outcome characteristics of private higher education and the job requirements in the private sector in Egypt. There is a strong negative (-.835) and significant (significance is less than 0.05 ) correlation between them. This means these two variables have a negative effect on the gap

Therefore, there is a relationship between the benefits of the higher education to the graduates, and the gap between outcome characteristics of the private higher education and job requirements in the private sector in Egypt.

Consequently, there is a relationship between the reasons related to the graduates themselves, and the gap between outcome characteristics of the private higher education and job requirements in the private sector in Egypt.

\section{Discussion}

The study aims at knowing the reasons leading to the gap (miss-fit) between the outcome characteristics of the private higher education and job requirements in the private sector in Egypt, identifying some techniques which lead to minimizing this gap and improving the private higher education to play its role in the fulfilment of the labour market requirements. Table (5) shows the research hypotheses and its results.

Table (5): The research hypotheses and the results of hypotheses testing

\begin{tabular}{|c|l|l|}
\hline \multicolumn{1}{|c|}{ Hypothesis } & \multicolumn{1}{|c|}{ results } \\
\hline H1 & $\begin{array}{l}\text { There is a relationship between reasons related to the Egyptian } \\
\text { society; and the gap between the outcome characteristics of the } \\
\text { private higher education and job requirements in the private sector } \\
\text { in Egypt. }\end{array}$ & $\begin{array}{l}\text { Was fully supported } \\
\text { by academics' and } \\
\text { businessmen's points } \\
\text { of view. }\end{array}$ \\
\hline H1.1 & $\begin{array}{l}\text { There is a relationship between the private higher education } \\
\text { perspective in Egypt, and the gap between the outcome } \\
\text { characteristics of the private higher education and job requirements } \\
\text { in the private sector in Egypt. }\end{array}$ & $\begin{array}{l}\text { Was fully supported } \\
\text { by academics' and } \\
\text { businessmen's points } \\
\text { of view. }\end{array}$ \\
\hline H2 & $\begin{array}{l}\text { There is a relationship between reasons related to the graduates } \\
\text { themselves; and the gap between the outcome characteristics of the } \\
\text { private higher education and job requirements in the private sector } \\
\text { in Egypt. }\end{array}$ & $\begin{array}{l}\text { Was fully supported } \\
\text { by academics' and } \\
\text { businessmen's points } \\
\text { of view. }\end{array}$ \\
\hline H2.1 & $\begin{array}{l}\text { There is a relationship between the benefits of the higher education } \\
\text { to the graduates, and the gap between the outcome characteristics } \\
\text { of the private higher education and job requirements in the private } \\
\text { sector in Egypt. }\end{array}$ & $\begin{array}{l}\text { Was full supported by } \\
\text { academics' } \\
\text { businessmen's points } \\
\text { of view. }\end{array}$ \\
\hline
\end{tabular}

The first hypothesis measures the relationship between the Egyptian society, and the gap between the outcome characteristics of the private higher education and job requirements in the private sector in Egypt. To test this hypothesis, the researchers tested one sub-hypothesis which represents the reasons related to the Egyptian society that can be considered cause of the gap.

For this sub-hypothesis, which measures the effect of the private higher education perspective in Egypt on the gap, the researchers found that the discrimination between majors, the vision of the community regards universities, and the vision of the community concerning scientific research are confirmed to be causes of the gap from the academic staff members' and businessmen's points of view. Consequently, the researchers can conclude that the society's perspective of the private higher education affects the gap between the outcome characteristics of the private higher education and job requirements in the private sector in Egypt.

Therefore, there is a relationship between reasons related to the Egyptian society, and the gap between outcome characteristics of the private higher education and job requirements in the private sector in Egypt. 
The second hypothesis measures the relationship between reasons related to the graduates themselves, and the gap between outcome characteristics of the private higher education and job requirements in the private sector in Egypt. To test this hypothesis, the researchers tested one sub-hypothesis which represents the reasons related to the graduates that can be considered causes of the gap.

For this sub-hypothesis, which measures the effect of the benefits of the private higher education to the graduates on the gap, the researchers found that there is a relationship between the benefits of the private higher education to the graduates, and the gap between outcome characteristics of the private higher education and job requirements in the private sector in Egypt.

Therefore, there is a relationship between reasons related to the graduates themselves, and the gap between outcome characteristics of the private higher education and job requirements in the private sector in Egypt.

Finally, the graduates were asked about their expectations from the university study. Their expectations were as follows:

- Obtaining a job quickly with a high salary that match the tuition they paid for the university.

- Fluency of foreign languages such as English, French... etc.

- Using computers and their applications fluently.

- Increasing the knowledge, experiences and skills related to their majors.

- Obtaining more applications and training during the study.

- The academic courses should reflect the current and future labour market requirements.

Also, the academic staff members were asked about the skills that the graduate should have from their studying in the Academy. Their answers were as follows:

- $\quad$ Fluency of foreign languages, especially English language.

- Using computers and software that are related to their majors.

- The students should be acquainted with the labour market, specializations requirements, and the available job opportunities in labour market.

- $\quad$ The ability to apply what they learn in their study in the practical life.

- $\quad$ The ability to think, create, and manage their time.

- $\quad$ The ability to solve problems, to make decisions, and to practice crisis management.

- The students should be acquainted with the information related to their majors and careers.

\section{Conclusion}

\section{- Reasons related to the Egyptian society}

With respect to reasons related to the Egyptian society, the researchers observed that the discrimination between majors, the vision of the community toward the universities' role, and the vision of the community toward scientific research are considered causes of the gap from the academic staff members' and businessmen's points of view.

\section{- Reasons related to the AAST graduates themselves}

For the reasons related to the AAST graduates themselves, the researchers found that the benefits of the graduates from higher education is considered one of the gap causes from the academic staff members' and businessmen's points of view.

\section{References}

Al-Husseini, S. and Elbeltagi, I. (2018), "The role of knowledge sharing in enhancing innovation: a comparative study of public and private higher education institutions in Iraq", Innovations in Education and Teaching International 55(1), 23-33.

Ali, A., Saeed, A. and Munir, A. (2018), “An Instrumental Perspective of Higher Education in Pakistan: From Public Good to Commercial Commodity”, Bulletin of Education and Research 40(3), 95-114.

Aring, M,(2012), "Youth and Skills: Putting Education to Work", background paper prepared for the Education for All Global Monitoring Report 2012. 
Assaad, R., Krafft, C. and Salehi-Isfahani, D. (2018), "Does the type of higher education affect labor market outcomes? Evidence from Egypt and Jordan", Higher education 75(6), 945-995.

Azam, A. (2018), "Service Quality Dimensions and Students' Satisfaction: A study of Saudi Arabian Private Higher Education Institutions", European Online Journal of Natural and Social Sciences 7(2), 275.

Barsoum, G. (2017), "Quality, pedagogy and governance in private Higher Education Institutions in Egypt", Africa Education Review 14(1), 193-211.

Beyleveld, M., de Villiers, J.J.R. and Fraser, W.J. (2019), "The use of active learning in a private higher education institution: the lecturer's perspective", South African Journal of Higher Education 33(2), 16-28.

EACEA (Education, Audiovisual and Culture Executive Agency). (2017), "Overview of the higher education in Egypt”, Erasmus+: International Capacity Building, Belgium.

El-Awady, N. (2013), "Higher education still suffering after the revolution", University World News.

Emira, M. (2014), "Higher education in Egypt since World War II: development and challenges", Italian Journal of Sociology of Education 6(2).

Hadidi, H.E. and Kirby, D.A. (2016), "Universities and innovation in a factor-driven economy: the performance of universities in Egypt”, Industry and Higher Education 30(2), 140-148.

Hicks, S., MacDonald, S. and Martin, E. (2017), "Measuring Student Attitudes and Performance in order to Improve Future Performance and Enrolments in Senior Science Subjects", International Journal of Innovation in Science and Mathematics Education (formerly CAL-laborate International) 25(3).

Hyde, G.D. (2013), "Education in modern Egypt (RLE Egypt): Ideals and realities”, Routledge.

Kottelenberg, M.J. and Lehrer, S.F. (2019), "How skills and parental valuation of education influence human capital acquisition and early labor market return to human capital in Canada", Journal of Labor Economics 37(S2), S735-S778.

Krafft, C. (2018), "Is school the best route to skills? Returns to vocational school and vocational skills in Egypt", The Journal of Development Studies 54(7), 1100-1120.

Maher, A. (2018), “Human Resources Management, Aldar Algameya: book, 3rd Edition”, Alexandria.

Nukunah, C.T.E., Bezuidenhout, A. and Furtak, A. (2019), "The contribution of a private higher education institution to the South African higher education landscape", South African Journal of Higher Education 33(1), 283-300.

Shah, M., Vu, H.Y. and Stanford, S.A. (2019), "Trends in private higher education in Australia", Perspectives: Policy and Practice in Higher Education 23(1), 5-11.

Tan, C.L., Goh, Y.N., Yeo, S.F., Ching, S.L. and Chan, H.S. (2017), "An examination of the factors influencing the green initiative and competitiveness of private higher education institutions in Malaysia", Jurnal Pengurusan (UKM Journal of Management) $\mathbf{5 1 .}$

Tolliver, D.E., Martin, A. and Salome, N. (2018), "Competency-based Education, Lifelong Learning and Adult Students: Insights from International Partnerships between East Africa, Southern Africa and USA-based Institutions of Higher Education", Journal of Pan African Studies, 12(1), 123-145.

Weiss, H.A. (2018), "Review of Liberating Service Learning and the Rest of Higher Education Civic Engagement", Journal of Political Science Education 14(2), 281-285.

Zlatkin-Troitschanskaia, O., Pant, H.A. and Coates, H. (2016), "Assessing student learning outcomes in higher education: Challenges and international perspectives”, 655-661. 